\title{
Nota
}

\section{First infestation record of Epicrates cenchria cenchria (Squamata: Boidae) by Porocephalus (Pentastomida: Porocephalidae) in Ecuador}

\author{
Primer registro de infestación de Epicrates cenchria cenchria \\ (Squamata: Boidae) por Porocephalus (Pentastomida: \\ Porocephalidae) en Ecuador
}

\author{
Glenda M. Pozo-Zamora and Mario H. Yánez-Muñoz
}

\begin{abstract}
Endoparasites of the genus Porocephalus, which mainly affect lungs of snakes, are distributed in Asia, Africa and America. In Ecuador, these parasites have been reported only for Boa constrictor. Here, we report the first record of infestation of Porocephalus in Epicrates cenchria cenchria from the Ecuadorian Amazon, based on examination of museum specimens. We found 26 parasitic individuals in 4 infected snakes, with a maximum of 16 individuals in a juvenile snake, and a minimum of 2 in an adult snake. Morphometric characters of the Ecuadorian populations of Porocephalus do not agree with those described for the genus. Therefore, we recommend a thorough analysis to define the taxonomic identity of these parasites.
\end{abstract}

Keywords. Ecuadorian Amazon. Hematophagous endoparasites. Lungs. Rainbow Boa. Snakes.

\section{Resumen}

Los endoparásitos del género Porocephalus, que infectan principalmente los pulmones de serpientes, se encuentran distribuidos en Asia, África y América. En Ecuador este parásito ha sido reportado únicamente en Boa constrictor. En el presente estudio reportamos los primeros registros de infestación de Porocephalus en Epicrates cenchria cenchria para la Amazonía ecuatoriana, basados en la revisión de especímenes de museo. Encontramos 26 individuos parásitos en 4 serpientes infectadas, con un máximo de 16 individuos en una serpiente joven y un mínimo de 2 en una serpiente adulta. La variabilidad morfométrica de las poblaciones ecuatorianas no encaja con las especies descritas de Porocephalus, por lo que recomendamos un análisis profundo para definir la identidad de estos parásitos.

Palabras clave. Amazonía ecuatoriana. Boa arcoíris. Endoparásitos hematófagos. Pulmones. Serpientes. 


\section{Introduction}

Pentastomida is a lineage of small worm parasites that comprises seven families (Christoffersen \& De Assis, 2013). These parasites are morphologically related to Ecdysozoa, but their phylogenetic relationships are still controversial (Christoffersen \& De Assis, 2015). The group is considered as modified crustaceans, and is probably related to the subclass Branchiura (Martínez et al., 1999; Lavrov et al., 2004). One of the families, Porocephalidae, is characterized by an indirect life cycle, which is completed when the intermediate host is consumed by the definitive host (Riley, 1986; Paré, 2008; Poore, 2012).

The genus Porocephalus consists of hematophagous endoparasites that affect the respiratory tract of several wild and domestic mammals (Riley, 1986) like primates, bats, dogs, mice, and opossums (Brookins et al., 2009; Pereira et al., 2010). The final hosts seem to be exclusively snakes (Fain, 1961; Riley \& Henderson, 1999; GómezPuerta et al., 2011; Poore, 2012; Christoffersen \& De Assis, 2013). Porocephalus includes 11 formally described species: 2 in Africa, 3 in Asia and 6 endemic to the American continent (Poore, 2012; Christoffersen \& De Assis, 2013).

The Brazilian Rainbow Boa, Epicrates cenchria cenchria, is a conspicuous snake with lateral ocelli on its body (CarvajalCampos \& Rodríguez-Guerra, 2017). It is widely distributed in South America East of the Andes, from eastern Guyanas, South of Venezuela to Bolivia (Passos \& Fernandes, 2008; Carvajal-Campos \& Rodríguez-Guerra, 2017).
Two species of Porocephalus have been reported as parasites of Epicrates cenchria cenchria in Peru, Brazil and Argentina: P. clavatus and Porocephalus sp. (Riley \& Self, 1979; Martínez et al., 1999; Gómez-Puerta et al., 2011; Chávez et al., 2015). In Ecuador, Riley \& Self (1979) recorded P. clavatus in an individual of the Redtailed Boa (Boa constrictor), without details of its specific location. In 2017, we examined rainbow snakes in the herpetological collection at the Instituto Nacional de Biodiversidad (INABIO) in Quito, Ecuador. We discovered the presence of Porocephalus in E. c. cenchria. Here we present the first formal record of this parasite in E. c. cenchria from the Ecuadorian Amazon.

\section{Materials and methods}

We dissected 13 specimens of Epicrates cenchria cenchria with a longitudinal incision at the pulmonary and ventral regions. The specimens are deposited at the herpetological division (DHMECN) in INABIO (Appendix 1). We measured and weighed the individuals infected with endoparasites (Table 1). Then we counted the removed parasites, deposited them in microtubes $(5 \mathrm{ml})$ in $70 \%$ ethanol solution, and examined the parasite specimens with a stereo microscope (Boeco 30x). Length was measured using a Buffalo digital caliper with a precision of $0.01 \mathrm{~mm}$. For taxonomic identification, we followed the parameters suggested by Riley \& Self (1979) and Christoffersen \& De Assis (2013).

Table 1. Measurements and weight of specimens of Epicrates cenchria cenchria infected by Porocephalus in the Ecuadorian Amazon. LHB: Length head-body, T: tail, HW: Head width.

\begin{tabular}{lllllllll}
\hline Specimens & Localities & Sex & Age & $\begin{array}{l}\text { LHB } \\
\mathbf{( m m})\end{array}$ & T (mm) & $\begin{array}{l}\text { HW } \\
(\mathbf{m m})\end{array}$ & $\begin{array}{l}\text { Weight } \\
(\mathbf{k g})\end{array}$ & $\begin{array}{l}\text { Number of } \\
\text { parasites }\end{array}$ \\
\hline $11884 \mathrm{DHMECN}$ & Zamora Chinchipe & $\mathrm{F}$ & SUB & 1110 & 136 & 25.20 & 0.55 & 16 \\
\hline $11280 \mathrm{DHMECN}$ & Zamora Chinchipe & $\mathrm{M}$ & SUB & 930 & 104 & 18.48 & 0.219 & 3 \\
\hline $11189 \mathrm{DHMECN}$ & Zamora Chinchipe & $\mathrm{F}$ & SUB & 1090 & 110 & 24.53 & 0.4 & 5 \\
\hline $0071 \mathrm{DHMECN}$ & Sucumbíos & F & ADU & 1710 & 185 & 23.83 & 1.15 & 2 \\
\hline
\end{tabular}




\section{Results}

Four of the 13 individuals of Epicrates cenchria cenchria were infected with pentastomids. The snakes were collected in two Amazonian provinces: one female from Sucumbíos, in northeastern Ecuador, at $400 \mathrm{~m}$ a. s. 1.; two females and one male from Zamora Chinchipe, in southeastern Ecuador, between 832 and $1398 \mathrm{~m}$ a. s. 1. We found a maximum of 16 parasites in a subadult female from Zamora
Chinchipe and a minimum of 2 in an adult female from Sucumbíos (Table 1).

A total of 26 parasites were counted, of which 23 were females and 3 were males. All of them were "hooked" to the lung walls (Figure 1A). The body length of female parasites was shorter in southern snakes $(\mathrm{N}=21)$ than in northern snakes $(\mathrm{N}=2)$ (Table 2, Figure 1B). The males presented genital pores and the females showed sensorial papillae (Figure 1C).

Table 2. Sex, measurements and number of annuli of Porocephalus species found in specimens of Epicrates cenchria cenchria from Ecuador. Min-max (average) \pm standard deviation.

\begin{tabular}{|c|c|c|c|c|c|}
\hline Specimens & Localities & $\begin{array}{c}\text { Number of } \\
\text { Porocephalus } \\
\text { individuals }\end{array}$ & $\begin{array}{c}\text { Sex of } \\
\text { parasite }\end{array}$ & Length (mm) & $\begin{array}{l}\text { Number } \\
\text { of annuli }\end{array}$ \\
\hline \multirow{2}{*}{11884 DHMECN } & \multirow{2}{*}{ Zamora Chinchipe } & 2 & $\hat{0}$ & $13-19(16) \pm 4.2$ & 34 \\
\hline & & 14 & q & $15-24(20) \pm 3.1$ & $32-37$ \\
\hline 11280 DHMECN & Zamora Chinchipe & 3 & q & $16.5-26.5(22.8) \pm 5.5$ & $35-36$ \\
\hline \multirow{2}{*}{11189 DHMECN } & \multirow{2}{*}{ Zamora Chinchipe } & 1 & $\lesssim$ & 14.4 & 32 \\
\hline & & 4 & q & $15.6-40(25) \pm 11.5$ & $34-37$ \\
\hline 0071 DHMECN & Sucumbíos & 2 & q & $44.9-63.7(54.3) \pm 13.3$ & $31-35$ \\
\hline
\end{tabular}

We assigned the obtained parasites to the genus Porocephalus based on the presence of an inflated head, not separated from the body by a neck on females, ringed body, mouth with a keyhole shape located between the hooks-line, and presence of internal simple-hooks and external doublehooks (cuticle extension) (Riley \& Self, 1979; Riley
$\&$ Walters, 1980). However, the assignation of a proper species rank was limited by the overlapping of certain measurements (e.g. body length and number of corporal segments), making difficult the differentiation between South American species of Porocephalus (P. crotali and P. clavatus) (Vargas, 1970; Riley \& Self, 1979). 

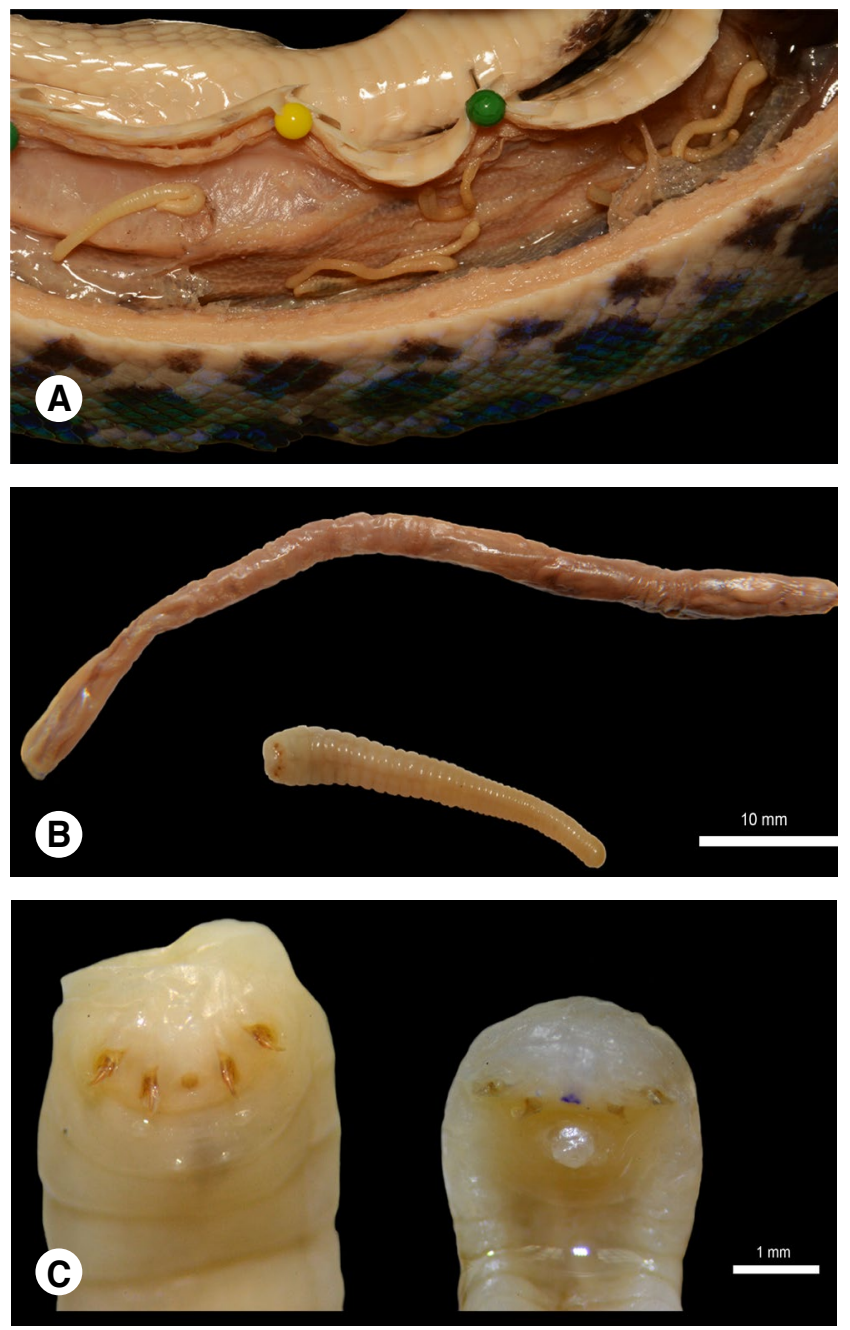

Figure 1. A. Specimens of Porocephalus sp. found in lung walls of Epicrates cenchria cenchria from the Ecuadorian Amazon. B. Difference in length between female of Porocephalus sp. from Sucumbíos (above), and Zamora Chinchipe (below). C. View of anterior end of female (left) and male (right) of Porocephalus sp. Photos by Mario H. Yánez-Muñoz.

\section{Discussion}

The size and number of annuli on the males and females of Porocephalus from the southern Ecuadorian Amazon are smaller (13-40 $\mathrm{mm}$; 32-37 annuli), than the previous records reported for others species from South America (P. basilicus, P. stilesi, P. clavatus, P. crotali, P. tortuguensis). The length range and number of annuli of the above- mentioned species are 44-102 $\mathrm{mm}$ and 35-49 annuli (Riley \& Self, 1979). Furthermore, the Porocephalus species from Northern Ecuador (Sucumbios Province) reached lengths (44.9-63.7 $\mathrm{mm}$ ) that overlap with those of females of $P$. clavatus (48-78 mm) and P. crotali (44-78 $\mathrm{mm}$ ) (Riley \& Self, 1979). However, the number of annuli is smaller than that reported for these two species: $31-35$ vs. $36-40 \mathrm{~mm}$, respectively.

We found a maximum of 16 individuals of Porocephalus infesting Epicrates cenchria cenchria, whereas in Bolivia, Ramos Tórrez et al. (2015) reported 40 individuals of Porocephalus stilesi in a sample of Lachesis muta. This is the highest documented number of these parasites per individual host for South America. The parasites in L. muta were found in the stomach and intestines; in our research Porocephalus specimens were extracted from the pulmonary region. The different regions where the parasites can be found might be related to the ontogenetic migratory behaviour of pentastomids (Martínez et al., 1999).

Porocephalus populations from Ecuadorian Amazon require a proper identification, as they do not fit with any described species of the genus.

\section{Acknowledgements}

We thank INABIO for facilitating this research and for access to the herpetological collection. M. Oviedo for her help in the identification of the sex of parasites. R. OjalaBarbour, M. Sánchez and J. Brito for their help in the translation and their comments to improve the manuscript. MYM offers special thanks to Mauro, Alejandra, Joaquín and Julieta Yánez for their continued support.

\section{References}

Brookins, M. D., Wellehan, J. F. X., Roberts, J. F., Allison, K., Curran, S. S., Childress, A. L. \& Greiner, E. C. (2009). Massive visceral pentastomiasis caused by Porocephalus crotali in a dog. Veterinary Patholo$g y, 46,460-463$. 
Carvajal-Campos, A. \& Rodríguez-Guerra, A. (2017). Epicrates cenchria. In Torres-Carvajal, O., G. Pazmiño-Otamendi \& D. Salazar-Valenzuela. (Eds.). ReptiliaWebEcuador. Version 2018.0. Recovered on October, 2017 from: https:/ / bioweb.bio/faunaweb/ reptiliaweb/FichaEspecie/Epicrates\%20cenchria.

Chávez, L., Serrano-Martínez, E., Tantaleán, M., Quispe, M. \& Casas, G. C. (2015). Parásitos gastrointestinales en reptiles en cautiverio en Lima metropolitana. Revista de Investigaciones Veterinarias del Perú, 26, 127-134.

Christoffersen, M. L. \& De Assis, J. E. (2013). A systematic monograph of the recent Pentastomida, with a compilation of their hosts. Zoologische Mededelingen, 87, 1-206.

Christoffersen, M. L. \& De Assis, J. E. (2015). Pentastomida Manual. Revista Ide@, Sociedad Entomológica Aragonesa. Accesible, 98A, 1-10.

Fain, A. (1961). Les Pentastomides de L'Afrique Centrale. Musée Royal de L'Afrique Centrale, Tervuren, Belgique Annales, Serie In $8^{\circ}$, Sciences Zoologiques, 92, 1-115.

Gómez-Puerta, L. A., López-Urbina, M. T. \& González, A. E. (2011). Presence of Porocephalus clavatus (Arthropoda: Porocephalidae) in Peruvian Boidae snakes. Veterinary Parasitology, 181, 379-381.

Lavrov, D. V., Brown, W. M. \& Boore, J. L. (2004). Phylogenetic position of the Pentastomida and (pan) crustacean relationships. Proceedings of the Royal Society, B: Biological Sciences, 271, 537-544.

Martínez, F., Troiano J. C., Gauna, L., Duchene, J., Stancato, J., Stancato, M., Núñez, S., Fescina, N. \& Jara, D. (1999). Frecuencia de infestación por pentastómidos en ofidios. Comunicaciones Científicas y Tecnológicas, 4, 58-60.
Paré, J.A. (2008). An overview of pentastomiasis in reptiles and other vertebrates. Journal of Exotic Pet Medicine, 17, 285-294.

Passos, P. \& Fernandes, R. (2008). Revision of the Epicrates cenchria complex (Serpentes:Boidae). Herpetological Monographs, 22, 1-30.

Pereira, W. L. A., Benigno, R. N. M. \& Silva, K. S. M. (2010). Fatal infections in a captive Pithecia irrorata (primate) by Porocephalus sp. (Pentastomida). Veterinary Parasitology, 173, 358-361.

Poore, G. C. B. (2012). The nomenclature of the recent Pentastomida (Crustacea), with a list of species and available names. Systematic Parasitology, $82,211-240$

Ramos Tórrez, L. A., Senzano Castro, L. M. \& Mancilla Montenegro, K. F. (2015). Nuevo registro de Porocephalus stilesi (Pentastomida) parasitando la serpiente Cascabel Púa (Lachesis muta, Viperidae) en las tierras bajas de Bolivia. Kempffiana, 11, 19-23.

Riley, J. \& Self, J. T. (1979). On the systematics of the Pentastomid genus Porocephalus (Humboldt, 1811) with descriptions of two new species. Systematic $P a-$ rasitology, 1, 25-42.

Riley, J. \& Walters, L. (1980). Porocephalus dominicana n. $\mathrm{sp}$. from the Dominican boa (Constrictor constrictor nebulosus). Systematic Parasitology, 1, 123-126.

Riley, J. (1986). The Biology of Pentastomids. Advances in Parasitology, 25, 45-128.

Riley, J. \& Henderson, J. (1999). Pentastomids and the tetrapod lung. Parasitology, 119, S89-S105.

Vargas, M. (1970). A contribution to the morphology of the eggs and nymphal stages of Porocephalus stilesi Sambon, 1910 and Porocephalus clavatus (Wyman, 1847) Sambon, 1910 (Pentastomida). Revista de Biología Tropical, 17, 27-89. 
Appendix 1. Specimens of Epicrates cenchria cenchria examined at the herpetological collection of the Instituto Nacional de Biodiversidad (INABIO) in Quito, Ecuador.

Epicrates cenchria cenchria (ECUADOR): Provincia Napo: Tena: DHMECN 0017, 0018, 0019: 563 m a.s.l.; Provincia Sucumbios: Lago Agrio, Cascales, Iwe, Reserva Ecológica Cofán Bermejo: DHMECN 8325: 312 m a.s.l.; Lago Agrio: DHMECN 0021, 0071: 400 m a.s.l.; Putumayo, Puerto Rodríguez: DHMECN 8693; 184 msnm; Provincia Orellana: Joya de los Sachas: DHMECN 6862: 274 m a.s.l.; Provincia Zamora Chinchipe: El Pangui, Concepción, ECSA: DHMECN 11189, 11279, 11280, 11884, 11885: 832-1398 m a.s.l.

\section{Glenda M. Pozo-Zamora}

Instituto Nacional de Biodiversidad

Quito, Ecuador

glenda.pozo@yahoo.es

http://orcid.org/0000-0003-0043-2834

\section{Mario H. Yánez-Muñoz}

Instituto Nacional de Biodiversidad

Quito, Ecuador

mayamu@hotmail.com

http://orcid.org/0000-0003-3224-1987
First infestation record of Epicrates cenchria cenchria (Squamata: Boidae) by Porocephalus (Pentastomida: Porocephalidae) in Ecuador

Citación del artículo: Pozo-Zamora, G. M. \& YánezMuñoz, M. H. (2019). First infestation record of Epicrates cenchria cenchria (Squamata: Boidae) by Porocephalus (Pentastomida: Porocephalidae) in Ecuador. Biota Colombiana, 20(1), 120-125. DOI: 10.21068/c2019. v20n01a08.

Recibido: 1 de junio de 2018

Aceptado: 30 de abril de 2019 